\title{
NUTRITIONAL AND PHYTOCHEMICAL SCREENING OF WILD FRUIT OF BERBERIS BALUCHISTANICA - AN ENDEMIC SPECIES TO PAKISTAN
}

\author{
RAHIM, B. Z. ${ }^{1}-$ QURESHI, R. $.^{2 *}-$ TAREEN, R. B. $^{1}-$ SHAZMEEN $^{2}$ \\ ${ }^{I}$ Department of Botany, Baluchistan University, 87500 Quetta, Baluchistan, Pakistan \\ ${ }^{2}$ Department of Botany, Pir Mehr Ali Shah Arid Agriculture University \\ Murree Road, Shamsabad, 46300 Rawalpindi, Punjab, Pakistan \\ *Corresponding author \\ e-mail: rahmatullahq@yahoo.com,rahmatullahq@uaar.edu.pk
}

(Received 29 ${ }^{\text {th }}$ Mar 2019; accepted $2^{\text {nd }}$ Jul 2019)

\begin{abstract}
Berberis baluchistanica Ahrendt is an endemic species to Pakistan belonged to Berberidaceae family. Its ripened fruit is collected by the natives and consumed as wild fruit. The present study aimed at evaluating nutritional and phytochemical potential of wild fruits of $B$. baluchistanica. The proximate analysis revealed that the fruit possessed highest proportion of dry matter $(92 \%)$, followed by crude fibre (35\%), moisture content $(8 \%)$, crude protein (7\%) and crude fat $(6.3 \%)$, while total ash percentage was the least $(3.5 \%)$. Mineral analysis indicated that iron $(\mathrm{Fe})$ was found in the highest quantity $(3.835 \%)$, followed by zinc $(1.039 \%)$, copper $(0.851 \%)$, manganese $(0.764 \%)$, potassium $(0.101 \%)$, while the sodium was in least amount. This study further determined five major phytochemical compounds such as alkaloids, flavonoids, phenols, tannins and saponins trough six solvent extracts. Alkaloids were detected by all solvents, except the aqueous extract. Phenols and tannins were detected by three solvent extracts. Flavonoids were isolated by two solvent extracts, while, saponins were only detected by the aqueous extract. Based on results, it can be concluded that the investigated fruit has great potential owing to substantial quantity of essential nutrients, minerals and phytochemicals and requires further detailed investigation prior to commercial production and introduction in the market.
\end{abstract}

Keywords: commercial production, essential nutrients, mineral analysis, phytochemical compounds, solvent extracts

\section{Introduction}

It is an established fact that use of fruits may improve the rate of human health Nwachukwu et al. (2010). Fruits provide nutrients including minerals, vitamins, antioxidants, polyphenols, etc. (Sher et al., 2003). Furthermore, fruits and vegetables possess fairly low calories, high dietary fibre and beneficial to human health (Khalil et al., 2013). These further aid in maintaining healthy weight and decrease the risk of numerous persistent illness Nwachukwu et al. (2010), like cardiovascular disorders, diabetes cancers, etc.

Pakistan has moderate diversity in ecological zones having range of plants. Since majority of the human population is residing in rural areas, so they are facing food insecurity and malnutrition. According to Chakraborty and Newton (2007), if the food with high nutritive value is safe, accessible, affordable and available for the reasonable population can form food security. During certain period of time, several food crops may turn into limited and expensive either during planting season or famine particularly for low income earners. Such consequences experience malnutrition and poor health. Owing to such issues, scientists are looking into screening the wild edible fruit which may have latent to balance staple food. 
Berberis baluchistanica Ahrendt, locally known as Tor Zaralag (Pashto) is an endemic to Pakistan belonged to Berberidaceae family. It is evergreen shrub up to $3 \mathrm{~m}$ tall with red to red-brown stem (Fig. 1). Leaves are thick, rigid, sub-orbicular to obovate-oblong, sessile to sub-sessile Flowers are approximately 7-10 mm across, yellow. Fruits are berries with ovoid to suborbicular shaped, dark red turned to black and pruinose blue. Its ripened fruit is collected by the natives and consumed as wild fruit. The decoction of roots has been reported in treating cough, infection and internal injury of human being as well animals (Ghafoor, 2002). Previously Abbasi et al. (2013) carried out antioxidant potential of leaves of Berberis baluchistanica. The present study aimed at evaluating nutritional, phytochemical and antioxidant potential of wild fruits of B. baluchistanica.

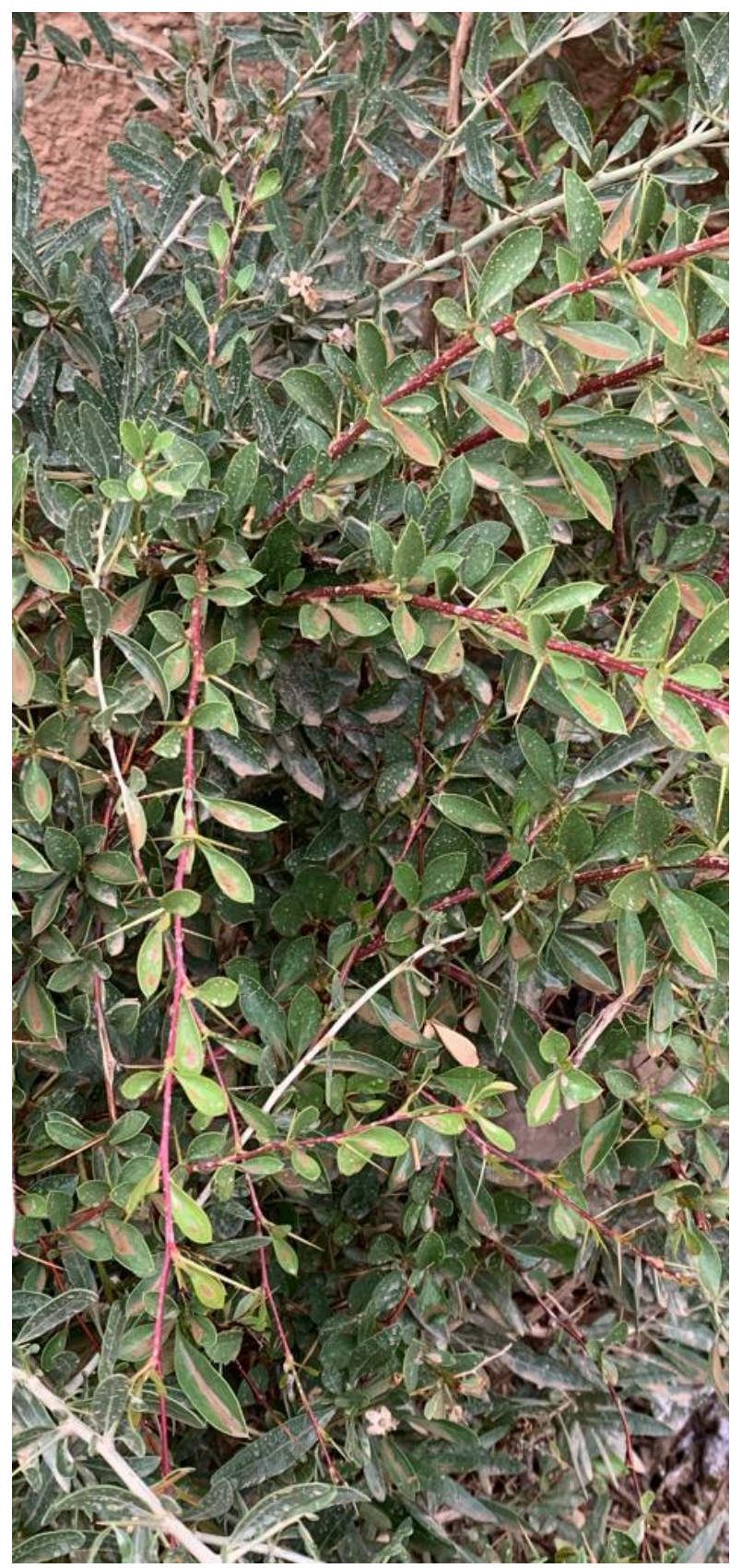

Figure 1. The habit of Berberis baluchistanica 


\section{Materials and methods}

\section{Location and area}

Ziarat district is located at $30^{\circ} 22^{\prime} 51 \mathrm{~N}$ and $67^{\circ} 43^{\prime} 37 \mathrm{E}$ at an altitude of $2453 \mathrm{~m}$ $(8050 \mathrm{ft}$ ) in the north Balochistan province, Pakistan (Fig. 2). Khilafat Hills are the highest peak with an altitude of $11.400 \mathrm{ft}(3.475 \mathrm{~m})$ in Ziarat district. Ziarat District has the highest Human Development Index of all districts in Balochistan (District Profile Ziarat, 1997). This district is famous for its antique and splendid juniper forest which spreads over 126,000 acres and is the second largest in the world. Some of the trees are almost 4,000 years old (Anonymous, 2019).

\section{Climate}

The climate of the study area is mostly dry temperate characterized by excessive cold during the winter season and refreshingly cool and pleasant in summer. Snow mostly falls during December to March. Mean annual precipitation is about $282 \mathrm{~mm} / \mathrm{year}$, mainly received during winter in the form of snow. Some showers also occur in July and August. Temperature extremes are characteristics feature of the area with mean maximum temperature of $28{ }^{\circ} \mathrm{C}$ recorded in July and August and mean minimum temperature of $-9{ }^{\circ} \mathrm{C}$ in January. The highest average relative humidity (67\%) was recorded in December, while the lowest (23\%) in October (Ahmed et al., 1990).

\section{Collection and identification of plant material}

The ripened fruits $(1 \mathrm{~kg})$ of Berberis baluchistanica Ahrendt were collected from the growing localities of Ziarat, Baluchistan during September to October, 2017 (Table 1). One set of voucher specimens of the species were prepared and identified by Dr. Rasool Bakhsh Tareen, Department of Botany, University of Baluchistan, Quetta. The determined specimens were deposited in the herbarium of Baluchistan University for record.

Table 1. Collection of fruits and plant specimens of B. baluchistanica from different growing localities of District Ziarat, Balochistan, Pakistan

\begin{tabular}{c|c|c|c|c}
\hline S. No. & Locality & Longitude & Latitude & Elevation (m) \\
\hline 1 & Ahmadun & $30^{\circ} 29^{\prime} 07.58^{\prime \prime}$ & $67^{\circ} 22^{\prime} 48.35^{\prime \prime}$ & 2100 \\
2 & Zargi & $30^{\circ} 30^{\prime} 12.99^{\prime \prime}$ & $67^{\circ} 41^{\prime} 18.99^{\prime \prime}$ & 2350 \\
3 & Zezri & $30^{\circ} 19^{\prime} 40.00^{\prime \prime}$ & $67^{\circ} 42^{\prime} 00.00^{\prime \prime}$ & 2500 \\
\hline
\end{tabular}

\section{Ethnobotanical investigation}

The traditional knowledge of Berberis baluchistanica was collected by using semistructured questionnaire following the work of Qureshi (2004) and Qureshi and Bhatti (2008). Regular field trips were arranged in order to collect information about the folk knowledge of plants.

\section{Proximate and mineral analysis}

The proximate analysis was carried out from the dried powdered sample by using standard method (AOAC, 2005). The powdered samples were analyzed for proteins, fat, 
carbohydrates, moisture and ash. The mineral composition was analyzed by using Atomic Absorption Spectrophotometer (Agilent Technologies Model No. 200 series) in the department of Botany, Pir Mehr Ali Shah Arid Agriculture University, Rawalpindi, Pakistan. For statistical analysis, standard error was determined from the triplicates readings.

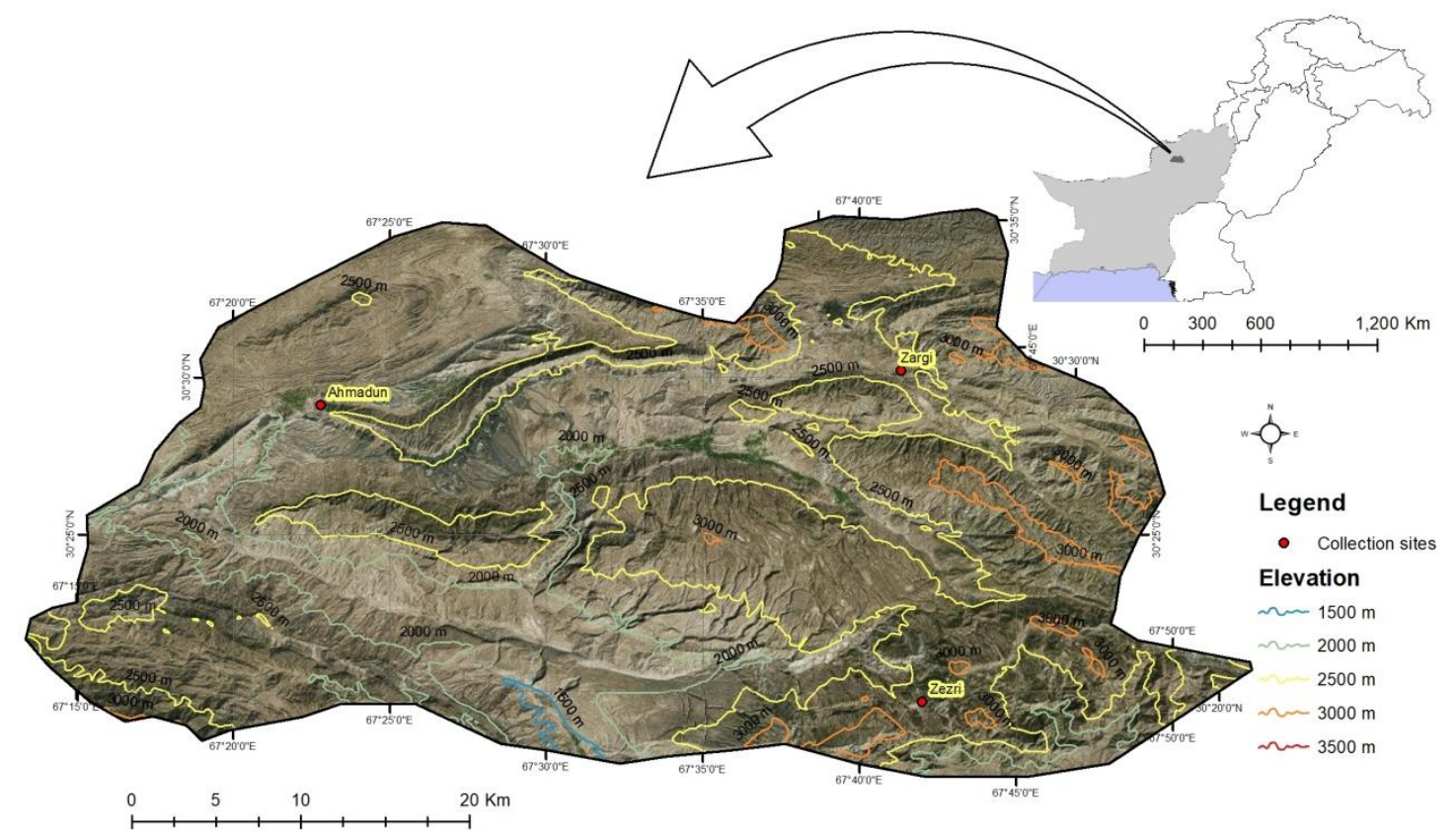

Figure 2. Location map of the study area and collection sites of the plant material

\section{Preparation of fruit extract}

The collected fruits were thoroughly rinsed with tap water and dried under shade. These were powdered to fine powder $(80 \mathrm{mesh})$ by using grinder (Model No. MX1100XT21CE) and preserved in airtight bottle and kept in refrigerator. The powder was soaked in six solvents such as acetone, aqueous, Ethyl acetate, methanol, n-hexane and petroleum ether. The same was then shaken at $37{ }^{\circ} \mathrm{C}$ for $24 \mathrm{~h}$. The same were subsequently sieved using Whatman filter paper (No. 1) and then concentrated on reduced pressure at $40{ }^{\circ} \mathrm{C}$ by employing rotary evaporator (Rahim et al., 2013). These extracts were used the phytochemicals screening.

\section{Determination of yield extracts}

The crude extracts yield percentage was carried out by using following formula after Dellavalle et al. (2011) and Rahim et al. (2013):

$$
\text { Yield } \%=\frac{\text { Weight of lyophilized extract }}{\text { Weight of dried fruit }} \times 100
$$

\section{Assay for phytochemicals screening}

The chemical assays were carried out from six different solvents based fruit extracts of the Berberis baluchistanica by using standard protocols for the detection of phytochemicals after Egwaikhide and Gimba (2007). 


\section{Analysis for alkaloids}

The $0.2 \mathrm{mg}$ fruit extract was warmed in $2 \%$ sulphuric acid for $2 \mathrm{~min}$. The filtrate was mixed in few drops of Dragendorff's reagent. The appearance of orange red precipitate confirmed the presence of alkaloids (Egwaikhide and Gimba, 2007; Rahim et al., 2013).

\section{Analysis for tannins}

A small quantity of fruit extract was liquefied in water and heated on water bath. Then it was filtered and few drops of ferric chloride were poured in it. The emergence of dark green colour revealed the occurrence of tannins in the sample (Egwaikhide and Gimba, 2007).

\section{Analysis for saponins}

The $0.2 \mathrm{~g}$ extract was forcefully shaken in $5 \mathrm{ml}$ of distilled water and boiled. The occurrence of bubble supposed to the presence of saponins (Egwaikhide and Gimba, 2007).

\section{Analysis for flavonoids}

The $0.2 \mathrm{~g}$ fruit extract was combined with diluted sodium hydroxide and few drops of hydrochloric acid were poured in it. This solution converted first into yellow colour and then colourless within few minutes. Such reactions indicated the presence of flavonoids in the test sample (Egwaikhide and Gimba, 2007).

\section{Analysis for phenolic compounds}

This test has two parts. In first part, $50 \mathrm{mg}$ of each solvent extract was added with $5 \mathrm{ml}$ distilled water and vigorously shaken for a minute. Then, five drops of $5 \%$ ferric chloride solution were supplemented. This mixture was resulted into dark green colour known as ferric chloride test. In the other test, $300 \mathrm{ml}$ of distilled water were added to $50 \mathrm{mg}$ of each solvent extract and shaken for a while. Then $3 \mathrm{ml}$ of $10 \%$ lead acetate were poured. The appearance of white precipitates in the resultant mixture showed the presence of phenolic compounds (Munazir et al., 2015).

\section{Results}

\section{Traditional uses}

The leaves and branches are dried and made into powder and is then dusted upon the injury and wounds to heal. Once sheep of hill was fired and after some time that sheep was observed under shadow of Berberis baluchistanica with repaired injury revealing that the injury was repaired by eating of the leaves of this plant. Wild fruits are collected by the local communities and eaten as nutritional as well as iron supplement.

\section{Extract yield}

Different solvent based extracts showed range of ratios in terms of extract yield and quantity (Fig. 3). The maximum amount of the extract yield was obtained by methanol $(12.95 \%)$. It was followed by water $(6.7 \%)$, ethyl acetate $(1.8 \%)$, acetone $(1.15 \%)$, while n-hexane and petroleum ether yielded less quantity (Fig. 3). 


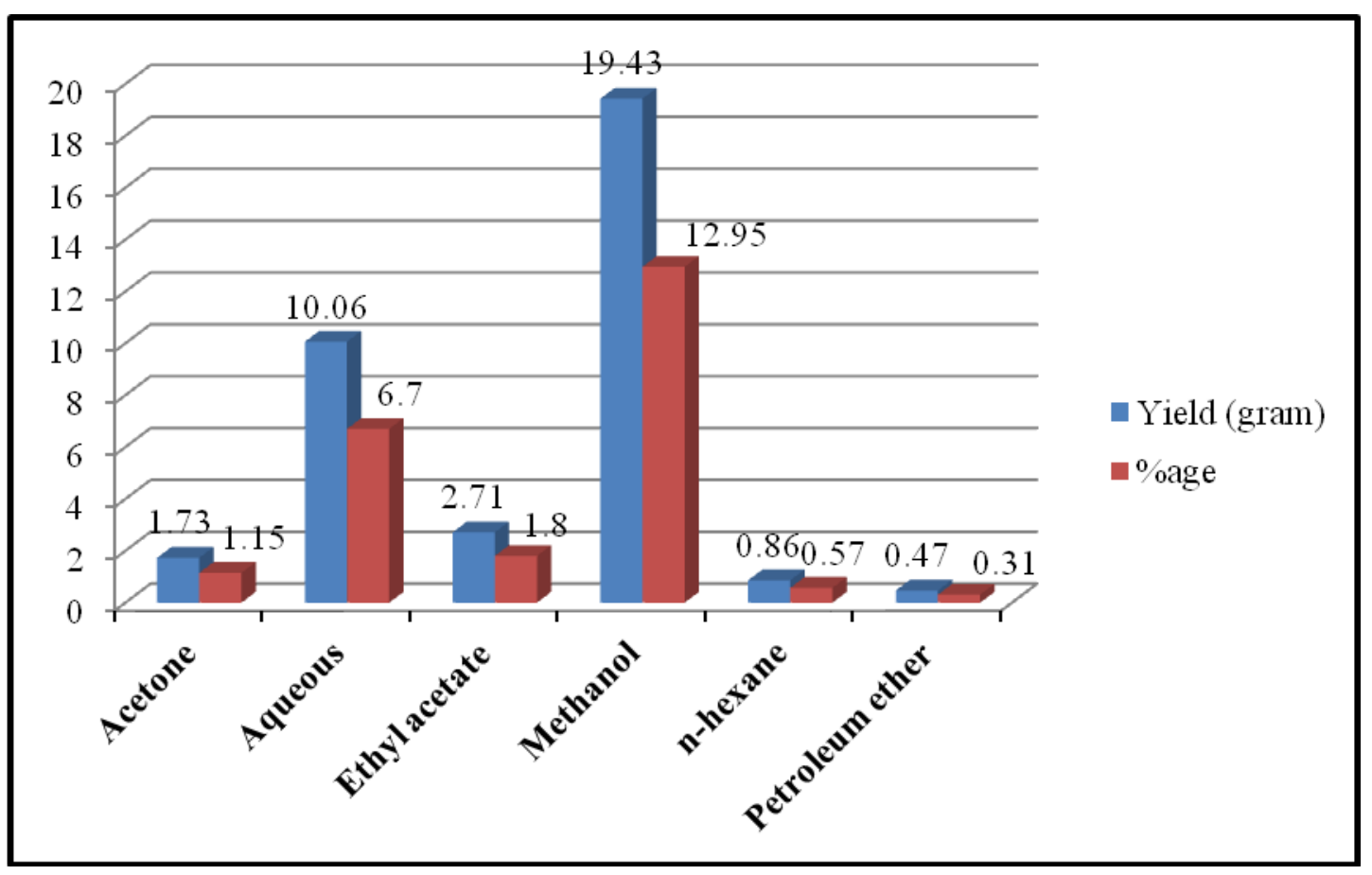

Figure 3. Yielding potential of various solvent based extracts from B. baluchistanica

\section{Proximate and mineral composition}

The proximate analysis of wild fruits of Berberis baluchistanica (Berberidaceae) was carried out and the data is provided in Figure 4. The data showed that the fruit possesses the highest proportion of dry matter (92\%), followed by crude fibre (35\%), moisture content $(8 \%)$, crude protein $(7 \%)$, crude fat $(6.3 \%)$, while total ash percentage was the least $(3.5 \%)$. It is apprising that the fruit retains an appreciable amount of all the beneficial elements. Iron ( $\mathrm{Fe})$ was found in the highest quantity $(3.835 \%)$, followed by zinc $(1.039 \%)$, copper $(0.851 \%)$, manganese $(0.764 \%)$, potassium $(0.101 \%)$, while the sodium was in lesser amount $(0.009 \%)$. The $\mathrm{Na} / \mathrm{K}$ ratio was found as 0.089 in the fruit (Fig. 5).

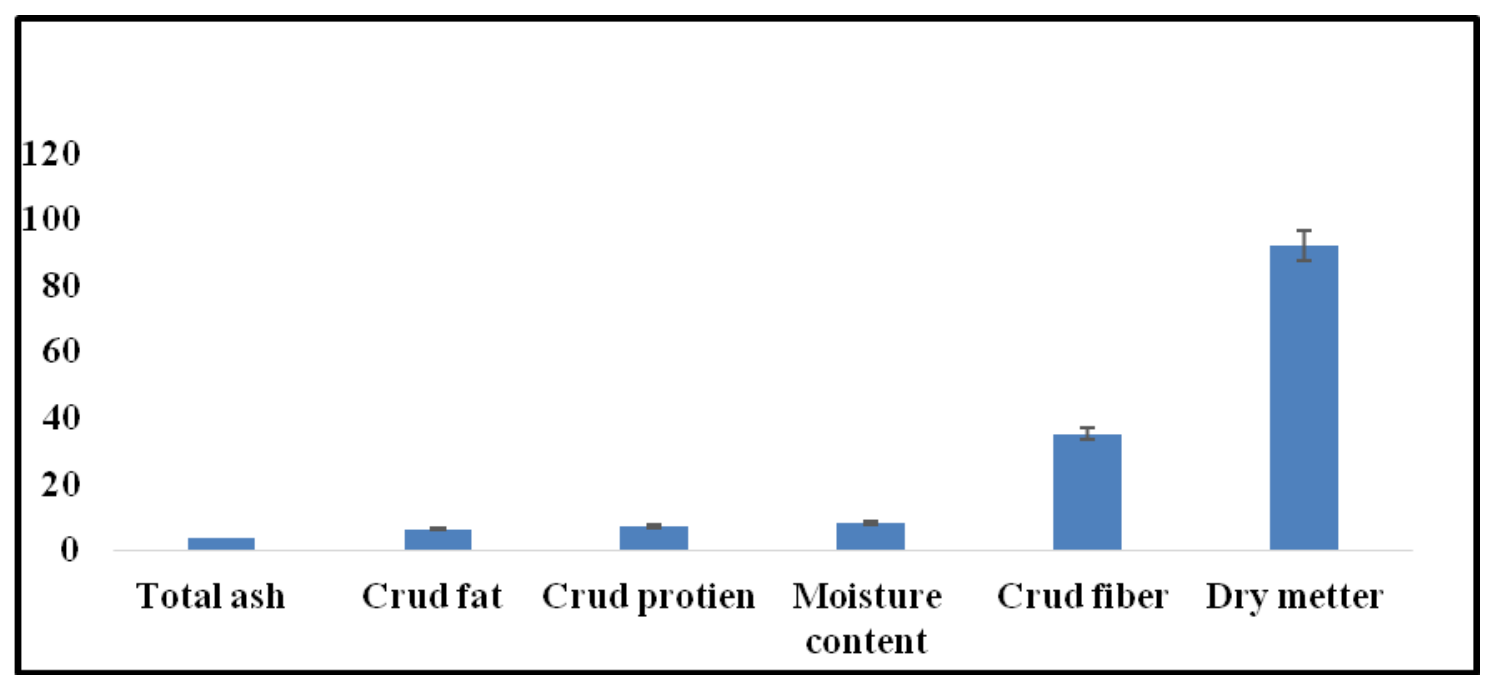

Figure 4. Graphical presentation of proximate analysis of B. baluchistanica 


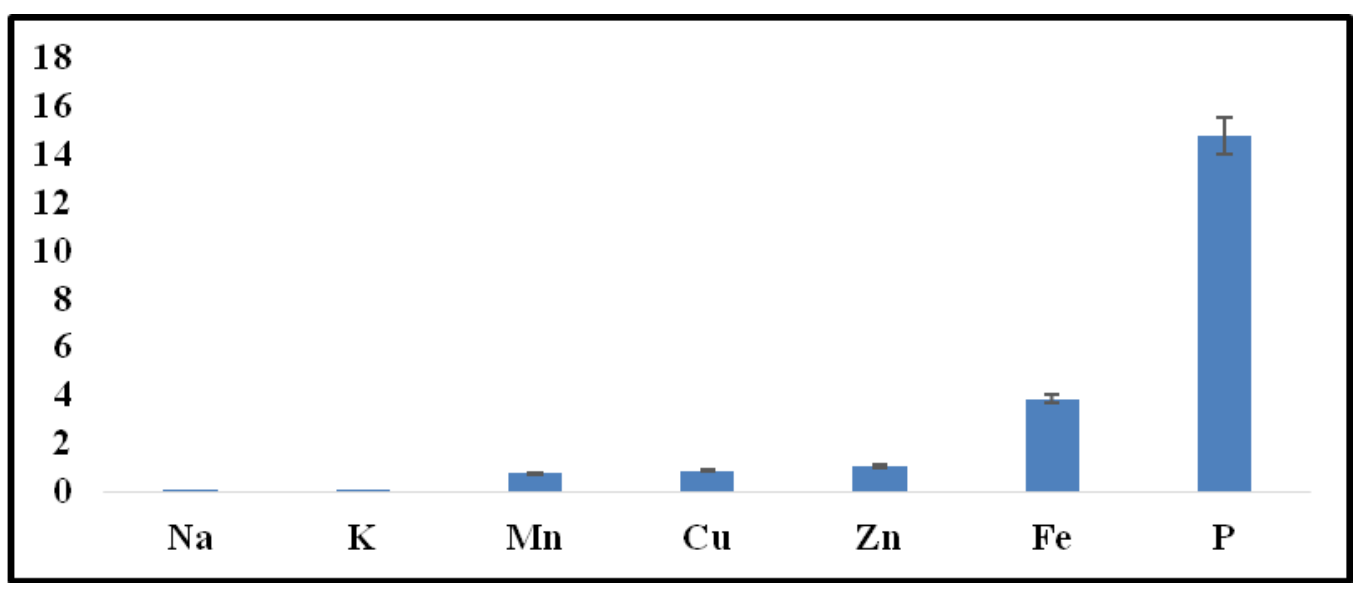

Figure 5. Graphical presentation of mineral analysis of B. baluchistanica

\section{Qualitative phytochemical screening}

The fruits of Berberis baluchistanica were screened for five major phytochemical classes namely alkaloids, flavonoids, phenols, saponins and tannins from six polarity based solvent extracts such as acetone, aqueous, ethyl acetate, methanol, n-hexane and petroleum ether. All the tested phytochemical classes were detected by various solvent extracts. Results of screening have been tabulated and shown in Figure 6.

In all, acetone and petroleum ether detected three groups of phytochemicals, while rest of the solvents such as aqueous, ethyl acetate, methanol and n-hexane screened two phytochemicals (Fig. 6). Alkaloids were detected by all solvents, except the aqueous extract. Saponins were only detected by the aqueous extract. Tannins were detected by three solvent extracts such as acetone, aqueous and ethyl acetate. The phenols were isolated by three solvent extracts like acetone, methanol and petroleum ether. In the case of flavonoids, it was detected by both the non-polar solvents i.e. n-hexane and petroleum ether.

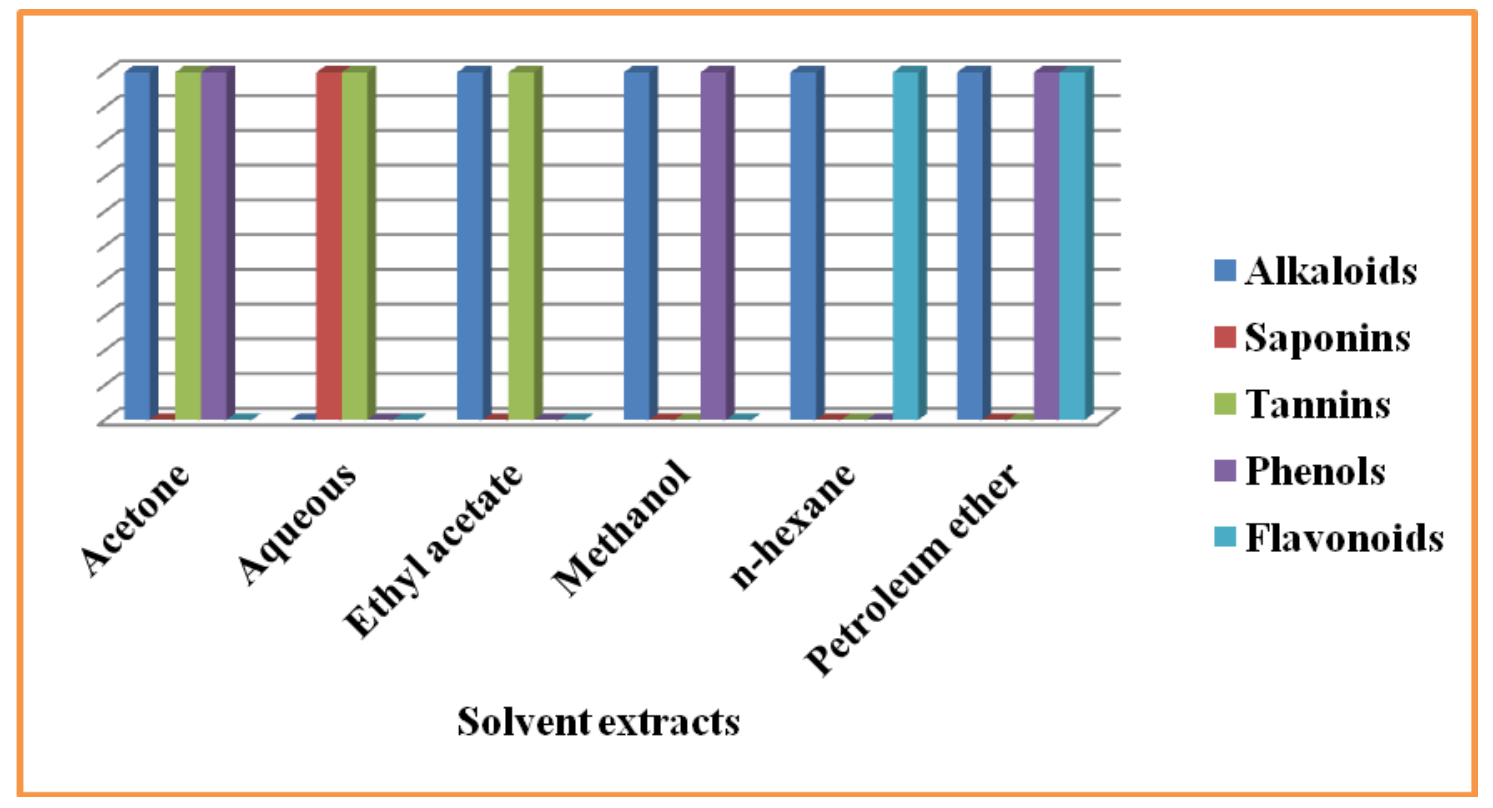

Figure 6. Phytochemical screening of Berberis baluchistanica solvent extracts 


\section{Discussion}

Due to food insecurity issues, indigenous wild fruits may alleviate nutrition deficiency especially in the case Pakistan being developing country. In order to test this hypothesis, the present research work was undertaken to investigate nutritional composition and phytochemical screening of wild fruit of Berberis baluchistanica.

The proximate and mineral analyses were carried out by employing the methodology of the Association of Official Analytical Chemists (AOAC, 2005). The results are shown in Table 1. It is apprising that the fruit retains an appreciable amount of nutritional and beneficial elements. The data showed that the fruit possesses the highest proportion of dry matter (92\%), followed by crude fibre (35\%), moisture content $(8 \%)$, crude protein $(7 \%)$, crude fat $(6.3 \%)$ and ash content.

Protein is a vital to diet and deficient of it results in causing various diseases. Foods over its $12 \%$ calorific values obtained from proteins are considered good source from plants (Pearson, 1976). This study revealed that wild fruit of Berberis baluchistanica possessed good amount of protein. The species possessed values higher than the reported species by Abbasi (2013) such as Prunus domestica, Grewia optiva, Juglans regia, Morus nigra, etc. The fruit is also contained $6.3 \%$ crude fat from Berberis baluchistanica which would be a good source of lipids.

The crude fibre contents were richly found in the fruits of Berberis baluchistanica (35\%). According to Ishida et al. (2000), taking fibre regularly can lower the jeopardy of cardiovascular disease including hypertension and diabetes as well as colon and breast cancer. The present results clearly indicated that the investigated wild fruits possessed higher values of dietary fibres that can mitigate human malnutrition.

It is worthwhile to mention that the moisture content was comparatively low in the tested fruit which may be due to drier conditions of soils. B. baluchistanica is growing in harsh climatic conditions such as poor in soil nutrition and less availability of moisture in hilly areas. Such conditions resulted in retaining lesser amount of moisture contents. It is evident from the results that the moisture content of the investigate fruit is low contrasting to that of Xylopia aethiopia (16.04) reported by Abolaji et al. (2007) and Acalypha hispida (11.91) by Iniaghe et al. (2009). Such results indicate that low moisture content is excellent for the long-term safeguarding from spoilage.

The ash content shows the presence of mineral contents in plant samples (Mammen et al., 2010). The fruits of B. baluchistanica possessed 3.5\% total ash content (Table 1). Abbasi (2013) reported low values of ash contents from traditional fruits. Summarizing the results of proximate analysis, it is evident from the results that the investigated wild fruit possess nutritional component and can be used a good source nutrition. According to the literature, the values of proximate composition of the evaluated wild fruits were either higher or at par with the previous studies (Imran et al., 2007, 2010). The variations in values might be due to varied climates, soils, seasonal collection, nutrients uptake by plant species, etc.

Iron $(\mathrm{Fe})$ was found in the highest quantity $(3.835 \%)$, followed by zinc $(1.039 \%)$, copper $(0.851 \%)$, manganese $(0.764 \%)$, potassium $(0.101 \%)$, while the sodium was in lesser amount $(0.009 \%)$. Our results far high as reported by Gani et al. (2018) who showed the data of various important fruits such as cherry. According to Davis et al. (2004), the mineral contents may be lower due to change of cultivars chosen for yield, rapid growth, pest resistance, herbivore resistance, etc. They are also in opinion that soil types and climate may also affect nutrient composition in food plants. 
This study was carried out to screen chief phytochemicals such as alkaloids, flavonoids, phenols, saponins and tannins from six polarity based solvent extracts of wild fruits of Berberis baluchistanica. The selected phytochemicals were detected by various solvent extracts (Fig. 6). Alkaloids were detected by all solvents, except the aqueous extract. All these phytochemicals are well known to have curative properties (Rabe, 2000). Among them, alkaloids are accounted as the chief therapeutic agent (Njoku and Akumefula, 2007).

Flavonoids are group of natural antioxidants which play an important role in combating the jeopardy of deteriorating cells (Okwu and Okwu, 2004). Plants may produce these compounds to mitigate microbial infection (Dixon et al., 1983). The present study detected flavonoids from n-hexane and petroleum ether. This is the important and copious group of phytochemicals present in many medicinal plants (Singh et al., 2007) which is responsible in reducing carcinogenic development, possesses anticancer and antimicrobial (Okwu, 2004; Lewis and Elvin-Lewis, 1995) and anti-inflammatory activities (Cushnie and Lamb, 2005).

From this study, tannins were detected by acetone, aqueous and ethyl acetate. This group is believed to hold anti-diarrheal, anti-fungal, anti-hemorrhoidal and anti-oxidant properties (Asquith and Butter, 1986). Besides, this compound possesses a bitter principle of drinks and foods (Chikezie et al., 2008).

The present study revealed the presence of saponins which was detected by the aqueous extract only. These secondary metabolites hold anti-inflammatory effect (Just et al., 1998) and also responsible in coagulating red blood cells that include development of foams in water solutions, haemolytic activity, cholesterol binding properties and bitterness (Trease and Evans, 1985; Lewis and Elvin-Lewis, 1995; Okwu, 2004).

\section{Conclusion}

This study revealed that the wild fruits of B. baluchistanica hold substantial quantity of essential nutrients such as protein, fibre, carbohydrates, fats, iron, zinc, copper, manganese, potassium and various important phytochemicals. This fruit is locally consumed by the natives and requires further investigation prior to commercial production and introduction in the market. Such kind of fruit supplement will help to meet the dietary requirement and improve the malnutrition problem in the country. Besides, presence of various secondary metabolites in the fruit also requires thorough investigation which may be used as plant based antimicrobial and antioxidant molecules.

Acknowledgement. This paper is extracted from the $\mathrm{PhD}$ dissertation of the first author.

\section{REFERENCES}

[1] Abbasi, M. A., Naqvi, S. S. H., Rehman, A. U., Tareen, R. B. (2013): Berberis baluchistanica: Assessment of natural antioxidants to reprieve from oxidative stress. International Research Journal of Pharmacy 4(5): 101-105.

[2] Abolaji, O. A., Adebayo, A. H., Odesanmi, O. S. (2007): Nutritional qualities of three medicinal plant parts (Xylopia aethiopica, Blighia sapida and Parinari polyandra) 
commonly used by pregnant women in the western part of Nigeria. - Pakistan Journal of Nutrition 6(6): 665-668.

[3] Ahmed, M., Naqui, E., Wang, E. L. M. (1990): Present state of juniper in Roadhmullazi forest of Baluchistan, Pakistan. - Pak. J. For. 227-236.

[4] Anonymous (2019): Ziarat-Government of Balochistan. https://www.balochistan.gov.pk/index.php?option=com_content\&view=article\&id=816\& Itemid=1102 (date of access: 25.05.2019).

[5] AOAC (2005): Official Method of Analysis. $18^{\text {th }}$ Ed. - Association of Officiating Analytical Chemists, Washington DC.

[6] Asquith, T. N., Butter, L. G. (1986): Interaction of condensed tannins with selected proteins. - Phytochem. 25(7): 1591-1593.

[7] Chakraborty, S., Newton, A. C. (2011): Climate change, plant diseases and food security: an overview. - Plant Pathology 60: 2-14.

[8] Chikezie, P. C., Agomuo, E. N., Amadi, B. A. (2008): Biochemistry: Practical Research Method. A Fundamental Approach. Vol. 2. - Mega Soft Publishers, Owerri, pp. 51-53.

[9] Cushnie, T. P., Lamb, A. J. (2005): Antimicrobial activity of flavonoids. - Int. J. Antimicrob. Agents 26(5): 343-356.

[10] Davis, D. R., Epp, M. D., Riordan, H. D. (2004): Changes in USDA food composition data for 43 garden crops, 1950 to 1999. - Journal of the American College of Nutrition 23(6): 669-682.

[11] Dellavalle, P. D., Cabrera, A., Alem, D., Larrañaga, P., Ferreira, F., Rizza, M. D. (2011): Antifungal activity of medicinal plant extracts against phytopathogenic fungus Alternaria spp. - Chilean Journal of Agricultural Research 71(2): 231-239.

[12] Dixon, R. A., Dey, P. M., Lamb, C. J. (1983): Phytoalexins: enzymology and molecular biology. - Adv. Enzymol. 55: 1-69.

[13] Egwaikhide, I., Gimba, C. E. (2007): Analysis of phytochemical content and antimicrobial activity of Plectranthus glandulosis whole plant. - Middle-East Journal of Scientific Research 2(3-4): 135-138.

[14] Gani, M., Jabeen, A., Majeed, D., Mir, S. A., Dar, B. N. (2018): Proximate composition, mineral analysis and antioxidant capacity of indigenous fruits and vegetables from temperate region of Indian Himalayas. - Journal of Food Measurement and Characterization 12: 1011-1019.

[15] Imran, M., Talpur, F. N., Jan, M. I., Khan, A., Khan, I. (2007): Analysis of nutritional component of some wild edible plant. - Journal of Chemical Society of Pakistan 29(5): 500-508.

[16] Imran, M., Khan, H., Shah, M., Khan, R., Khan, F. (2010): Chemical composition and antioxidant activity of certain Morus species. - Journal of Zhejiang University - Science B (Biomedicine \& Biotechnology) 11(12): 973-980.

[17] Iniaghe, O. M., Malomo, S. O., Adebayo, J. D. (2009): Proximate composition and phytochemical constituents of leaves of some Acalypha species. - Journal of Nutrition 8(3): 256-258.

[18] Ishida, H., Suzuno, H., Sugiyama, N., Innami, S. Todokoro, T. (2000): National evaluation of chemical component of leaves stalks and stem of sweet potatoes. Ipomea batata Poir. - Food Chemistry 68: 359-367.

[19] Khalil, A. T., Khan, I., Ahmad, K., Khan, Y. A., Khan, M., Khan, M. J. (2013): Synergistic antibacterial effect of honey and Herba Ocimi Basilici against some bacterial pathogens. - Journal of Traditional Chinese Medicine 33: 810-814.

[20] Lewis, W. H., Elvin-Lewis, M. (1995): Medical Botany: Plants Affecting Mans Health. John Wiley Interscience, New York.

[21] Mammen, D., Daniel, M., Sanert. (2010): Variations in values of proximate analysis in Aerva lanata Juss ex Schultes, Hedyotis corymbosa (L.) Lam. and Leptadenia reticulata (Retz.) W. \& A. - International Journal of Pharma and Bio Sciences 1(4): 629-636. 
[22] Munazir, M., Qureshi, R., Munir, M. (2015): Preliminary phytochemical screening of roots and aerial parts of Leptadenia pyrotechnica. - Pakistan Journal of Botany 47(2): 659-664.

[23] Njoku, P. C., Akumefula, M. I. (2007): Phytochemical and nutrient evaluation of Spondias mombin leaves. - Pakistan Journal of Nutrition 6(6): 613-615.

[24] Nwachukwu, C. U., Umeh, C. N., Kalu, I. G., Okere, S., Nwoko, M. C. (2010): Identification and traditional uses of some common medicinal plants in Ezinihitte Mbaise L. G. A., of Imo State, Nigeria. - Report and Opinion 2(6): 1-8.

[25] Okwu, D. E. (2004): Phytochemicals and vitamin content of indigenous species of southeastern Nigeria. - J. Sustain. Agric. Environ. 6(1): 30-37.

[26] Okwu, D. E., Okwu, M. E. 2004. Chemical composition of Spondias mombin Linn. plant parts. - J. Sustain. Agric. Environ. 6(2): 140-147.

[27] Pearson, J. (1976): Determination of Phytic Acid and Phosphorus Content of Biological Materials. - Cambridge University Press, London.

[28] Rabe, T. S. J. (2000): Isolation of antimicrobial sesquiterpenoid from Warbugie salutarius. - Journal of Ethnopharmacology 93: 171-174.

[29] Rahim, G., Qureshi, R., Arshad, M., Gulfraz, M. (2013): Phytochemical analysis and antioxidant properties of Teucrium stocksianum flower from Malakand Division, Pakistan. - International Journal of Agriculture \& Biology 15(2): 377-381.

[30] Sher, H., Midrarullah, Khan, A. U., Hussain, F., Ahmad, S. (2003): Medicinal plants of Udigram, District Swat, Pakistan. - Pakistan Journal of Forestry 53(1): 65-74.

[31] Singh, R., Singh, S. K., Arora, S. (2007): Evaluation of antioxidant potential of ethyl acetate extract/fractions of Acacia auriculiformis. - Food Chem. Toxicol. 45(7): 1216-23.

[32] Trease, G. E., Evans, W. C. (1985): Pharmacognosy. 12 ${ }^{\text {th }}$ Ed. - English Language Books Society, Bailliere Tindall. 